\title{
Life Insurance Contract: Similarities and Differences between Albanian Civil Code and Italian Civil Code Provisions
}

\author{
Ph.D. Ersida Teliti \\ Lecturer, Faculty of Law, University of Tirana \\ M.Sc. Romina Damini \\ Master of Science, Faculty of Law, University of Tirana
}

\section{Doi:10.5901/mjss.2014.v5n2p463}

\begin{abstract}
Nowadays, the insurance activity is developed widely. The developing countries are getting different strategies in order to stimulate the insurance activity. The main aim is to favor not only obliged insurance contract, but also other forms of insurance contract, such as: life insurance contract. This article offers in a comparative view the general rules on life insurance contract between Albanian Civil Code and Italian one. Its aim is to underline the similarities and the differences on the provisions of this contract. Also, a special focus is on life insurance contract in benefit of a third person. The provisions of this contract express clearly the relation between two Civil Codes, as we are part of Civil Law Family. In addition, another important connection is the fact that the second part of Albanian Civil Code follows the same rules as Italian Civil Code. Through this article, the authors try to give a form to their effort on writing and being part of big academic doctrine.
\end{abstract}

Keywords: Life insurance contract, the insurer, the insured, insurance policy, third person.

\section{Introduction}

Life insurance contract is an agreement between the insured and insurer. Under the terms of the life insurance contract, the insurer promises to pay a certain amount of money if the insured loses his life, as an exchange for the paid premium. If an accident happens the injured person will be forced to break away from his activity temporarily or permanently. This would bring considerable financial damage, besides the medical expenses, also the inability to work. Life insurance contract is a matter of mentality in all developing countries. Often we feel the need for life insurance, only when an accident occurs, or if the accident occurs in the family. Insurance products, which are known as insurance policies, in simplest terms replace something that is damaged or lost. Insurance products are divided into two groups: general ones and life ones. General Insurance are those securities that are used to secure assets such as property, cars etc.

Life insurance is a product that is sold in each individual state and is subject to the regulations and laws that exist where policies are sold. Each state has its own department of insurance, which regulates the policy requirements for products such as life insurance. Many of these requirements are designed to provide protections to the consumer who is purchasing various types of insurance products that are provided by an insurer.

The price of insurance, referred to the insurance premium is calculated according to what is provided, value, time and duration of the insurance policy. In life insurance, which is calculated in the same way plays a key role the age of the person who will be insured, health status and duration of life insurance. Insurance companies do not issue life insurance policies for people who suffer from incurable disease or for persons over a certain age (usually this limit varies from 60 to 65 years).

\section{The History of Life Insurance}

Life insurance is simply the contract between a single individual and an insurance company dictating that the company should pay the policy holder's beneficiary if the insured dies. Life insurance started in the city of Rome. The people of this highly advanced civilization decided to form what they called "burial clubs". These clubs were designed with one sole purpose, in case of an unexpected death of a club member; everyone else would be willing to pay for their funerary expenses and help the family of the survivor with some money. The concept of life insurance ended dramatically in the 
year 450 A.D. when the Roman Empire fell and its practices were abandoned for a long period of time. It is also important to highlight that many historians agree that about at the same time of Rome, the Indian Empire and its citizens also formed "burial clubs" in order to pay for funerals and help people with expenses.

Modern life insurance however did not start until the British decided to try and make it work. The practice of life insurance was banded in the entire continent of Europe except for England and it was exactly the British that started the most prominent life insurance companies known to the European countries today. It was in the middle of the 17th century that in the streets of London, England a group of people met together at Lloyd's Coffee house and decided to come about with life insurance ideas. The coffee house was a famous place for merchants, ship owners and traders and therefore it would be the perfect place to discuss life insurance knowing that most of those people had money. With the British knowing the basics of life insurance and the things that could help people like the life insurance industry, they decided to give it a try in the United States of America. After talking about how they would decide on coming about with the first life insurance company, they decided to base it on the well known British model at the time. The 1900's proved to be an era of growth for the life insurance industry. Two wars went on and many people decided to insure themselves to establish a secure monetary future for their families. People decided that not having protection was not worth it and that a little premium each month was better than leaving their families in economic burden.

\section{Characteristics of the Insurance Contract}

The insurance contract is a very important contractual relationship in civil circulation. In recent decades has been a great development of the insurance market, which is a quantitative or qualitative development. To understand the importance of the insurance contract in life of a national community is not sufficient the description of the essential characteristics of this contract, but is also important the social changes description of the contractual subjects. Quantitative developing has to do with the increasing number of citizens, who address to the insurance institute, and the qualitative with the insurance brokers, who offer better possible insurance contracts conditions.

Insurance contractual development in Albania was fixed since the time of the Albanian state birth, but the first legal regulation is arranged with the approval of the Albanian Commercial Code, 1932. During the years after the Second World War, this contract was arranged with the law "On legal actions and obligations" and later by Decree no. 4209 " On state institution of deposits and obligations" 1967. In addition, the Civil Code, 1981, fixes insurance contract with its provisions. The insurance contract meaning is given in the Article 1113 of Albanian Civil Code, 1994, which provides:

"In the insurance contract the insurer is obliged: a) to compensate the damage to the other party or a third person in the case of insurance property, within the limits of the amount stipulated in the contract, $b$ ) in the case of live insurance to pay the other party or a third person, for whom the contract is connected, the amount of insurance provided in the contract. The insured must pay the premium (price of insurance) specified in the contract. The insurer may be a public or private subject."

We can also do a comparative study between the regulation mode of this contract by the Albanian and Italian law, highlighting the commons and the differences of the both legislations about the insurance contract.

Italian Civil Code, as well as the Albanian Civil Code, in its provisions explicitly gives terms of the insurance contract, defining it in the article 1882:

"Insurance is a contract whereby the insurer, against payment of a premium, undertakes to repay the insured, within the agreed limits, the damage caused to him from an event, or to pay a principal or an annuity upon the occurrence of an event relating to human life."

Insurance contract definition of Albanian Civil Code is almost identical to Italian Civil Code definition, since the Albanian Civil Code legal regulation was taken by the Italian Civil Code. The only difference between Italian and Albanian law regarding the meaning of the person insurance contract is the fact that in Italian law is explicitly provided that the insurer can also pay a rent of life in favor of the insured with the occasional occurrence ensuring that causes damage to life or his health, which is not foreseen in Albanian law.

Italian Civil Code provides that insurers are only legal entities. Also, a certain category of legal entities are excluded from the possibility to exercise their activities in the field of insurance, such as the joint stock companies, which are regulated by special laws. One of the most important elements of insurance contract is the risk, the possibility that something undesired happens.

So, the aim of insurance contract is to transfer the risk from the insured to the insurer. When the risk on the case 
of insurance will happen, the economic consequences will be carried on the insurer. Both Civil Codes have given importance to the rules on the insurance case and the risk, expressing clearly the connection between them. Also, it is a strong relation between the insurance case and the price of insurance. The existence of the risk effects directly to the validity of contract, producing invalidity.

Another characteristic of the Italian civil law concerning insurance contract, which is not provided in Albanian law is that Italian law has made specific determinations regarding bid or proposal that the insured makes for the insurance contract.

Law provides that in cases where the insured submits a written offer for concluding insurance contract, he is bound by his proposal. The insured has to wait the insurer answer for a period of 15 days, or the maximum 30 days when it becomes necessary to advance medical examination of the insured. Law has determined that this period begins from the date of proposal submission to the insurer.

Albanian Civil Code doesn't have any provision regarding the offer that the insurer could make to the insured must be written. It is solemn formal contract according to the Albanian Civil Code, which has provided that in absence of such written form, the contract is void. The purpose of this written form of the contract is for the validity of the contract (ad substantiam) .

The insurance contract law should be in the form of an insurance certificate or insurance policy issued by the insurer to the insured. This indicates that the legislator has not only limited autonomy of the will of the parties, in the sense that this autonomy will be vested in a certain way that is a written form, but also provides concrete way how the contract should be drafted, which is the evidence of insurance or insurance policy.

The Article 1888 of the Italian Civil Code provides that the insurance contract must be proved that the contract is concluded in writing, which can be translated in Albanian legal language in this way: "The insurance contract must be concluded in writing in order to be proved in third parties."

From the above we conclude that the differences between Italian Civil law and the Albanian one is that Albanian law requires a written insurance contract in order to have a valid contract. In other words, it is a condition for the validity of the contract. On the other hand, the Italian law requires a written contract in order to be proved in third parties and if it is not written, the contract is still valid, but it cannot be proved by witnesses.

Another difference between Italian and Albanian legislation related to the form of the insurance contract, although no less important, is that the Albanian law does not allow any other form of insurance contract, except insurance policy which is issued by the insurer in any case. Albanian law is rigid in this regard and otherwise the contract is void. As the economic, financial and social level between the two countries is different, Italian law has provided a special form of insurance contract; an insurance contract which may be in the form of a title to bearer. The law stipulates that if the contract is connected in this form, the transfer of insurance policy brings the transfer of the credits rights, with the same effects as Credit assignment, due to the fact that the insurance policy issued in the form of title to bearer is freely transferable from one subject to another, without any formality. Both Civil Codes, article 1899 of Italian Civil Code and article 1124 of Albanian Civil Code provide that insurance contract becomes effective at 12 am on the concluding day of the contract and ends at $12 \mathrm{pm}$ on the last day of the term of the contract. If this exceeds ten years, the parties despite agreement to the contract may be entitled to terminate the agreement by having a notice within six-months.

\section{The Parties in the Life Insurance Contract}

Life insurance contract is one of insurance contracts in general. It is exclusively related to occurrence of events, which has to do with the insured's life. It is necessary to emphasize that Albanian Civil Code has clearly expressed, the life insurance contracts could be related with events that has to do with the life and work ability of the insured.

The content of the life insurance contract consists on the rights and obligations of the insured and insurer. There are a lot of common provisions on both Civil Codes, but also a lot of differences. Albanian Civil Code defines as an insured person any private person, except the people who suffer from alcoholism, narcotics, mental diseases because these persons cannot understand the importance of their actions and cannot take care for themselves too, also people more than 70 years.

One of the most important obligations in life insurance contract as we have mentioned on this paper is the insurer payment of a premium, which should be paid within the agreed limits on the contract. The article 1882 of Italian Civil Code, which gives the definitions of insurance contract, specifies that this is related to the occurrence of an event relating to human life. Through the method of literal or extended interpretation, this means that the insurer is a natural person or legal one could not have a human life. 
The right of the insured to designate another person to obtain the amount of insurance, with the occasional occurrence of insurance is a right predicted only by Albanian legislation, under which the insured may assign in the contract of insurance, if he dies the insurance amount will be paid to a member of his family, another person, state, or a public legal entity, but not to a private legal entity.

The insured is entitled to determine to the insurance contract the person who will benefit the amount of insurance after his death, but also he has the right to replace this person with another one. To do so, the insurer is obliged to notify the insurer, and to present insurance contract in order to make the required entries. He is not obliged to inform the person, whom he had earlier designated as beneficiary insurance amount. In order to make this replacement in the contract it is imperative that the contract still be in force.

Both legislations provide the insured's right to revoke the person, who is entitled to benefit the amount of insurance after the insured death.

\section{Insurance Policy}

The insurance policy is one of the most important elements of insurance contract. As it is mentioned above, the importance of it is different in Albanian Civil Code and Italian one.

The insurer is obliged to give to the insured the insurance policy, which should be signed by him. The Albanian Civil Code does not provide any other form for the insurance contract, only the insurance policy through the condition of validity. The Italian Civil Code, besides the insurance policy, based on the principle of autonomy of will, has let open the possibility to give another form to the insurance contract. In this case, the form of contract has only to be proved, so it does not have effects on the validity of it.

The importance of insurance policy is provided on the other articles, where it is clearly expressed in case of losing it, the insurer should give a duplicated copy of it to the insured, with the same legal effects.

Albanian Civil Code has listed the most important elements that the insurance policy should have, such as: the identities of the insurer and the insured, the insurance case, the period on which the contract has effect, the insurance premium and the conditions of its payment. This code has expressed the necessity to mention and to be part of insurance policy the third person in benefit of the insurance contract.

The insurance policy should clearly rule the conditions of decreasing the amount of insurance and termination of contract, so that the insured or the third person that benefit of it may have knowledge on it. Even that Albanian Civil Code has not any provision on this case, it is a necessity to be a prediction of it in the insurance policy.

Both Civil Codes, indirectly, express the right of the insurer to provide all the conditions of the contract by himself through the insurance policy. That's why the insurance contracts, in particular, are standard contracts. Referring to general predictions on the institute of interpretation of contract, the articles on insurance policy, which are not clear, should be interpreted on favor of the insured.

\section{Life Insurance Contract in Benefit of a Third Person}

Both Civil Codes specify life insurance contract can be concluded even providing life of a third person. In this case, the assignment of a third person may be done either by the parties in the insurance contract, or by a later written statement, or even by testament. This provision shows that at the life insurance contract is allowed the conclusion of the contract in benefit of the third person, as allowed even at the property insurance contract and this is one of the many similarities between them. This provision specifies that at life insurance contract, this contract can be stipulated in benefit of a third person in one of these ways:

First: By determining the name of the third person in life insurance contract concluded by the insurer and the insured. This is the common way of concluding life insurance contract, in benefit of a third person, where the insured party declares that through this contract, he will insure the life of a third person, noting in the life insurance contract, where he had insured his life, the name of the third person who is going to benefit from this contract.

Second: By a subsequent written statement which the insured shall address to the insurers. In this case, the life insurance contract in benefit of a third person, takes legal effect at the time that the written statement of the insured arrives to the insurer and the insurer agrees to enter into this contract.

Third: From the testament. This is a specific case of the insurance contract in benefit of a third person and it starts to cause legal consequences only after death of the testator and after the opening of testamentary evidence.

Albanian Civil Code does not provide anything about the will of the beneficiary when the life insurance contract is 
related in benefit of a third person, in the articles where the insurance contract is regulated. This means that the will refers to general articles, where the contract in benefit of a third person is ruled. It is necessary to underline the importance of the expressed will of the third person. This contract will produce the effects only after the third person will accept this contract in benefit of him.

With the occurrence of the insurance case provided in the life insurance contract, in this type of contract based on the will of the insured the amount of insurance has not to be paid to the person who has signed the contract, but should be paid to a third person. This insurance amount, after the death of the insured, according to the Albanian Civil Code is not included in the inheritance of the insured. This means that the amount of insurance will be paid exclusively to the third person and heirs of the insured will not pretend any right on it.

Italian and Albanian Civil Code provide also the cases when the insurance contract is stipulated by a person on behalf of another person, without the right of the person who enters into the contract on behalf of others, to do so or not being authorized to signing of the contract by the other person.

Another response given by Italian Civil Code is that in this case, the interested person may express his will on approving this contract, even after the contract has expired or the insurance case is verified.

When the contractor enters into an insurance contract on behalf of another person, without having a right to act like this, the contractor is obliged personally to accomplish the contractual obligations derived from contract, until the insured expresses his written approval or rejection of the contract. Also, the contractor is obligated to pay in favor of the insurers the relative insurance premiums for the duration of contract, until the person in whose favor the contract was entered into, makes its approval or rejection.

Another legal situation is provided by Italian law, which deals with cases when the insurance contract is stipulated by the contractor, on behalf of another person. In these cases the insurance contract is stipulated or by power of attorney or by an order contract on the basis of which the contractor operates by his own, but on behalf of the insured. When the contractor acts on behalf of another person for the stipulation of the insurance contract, he is obliged to fulfill all obligations arising under the contract, except those that are closely related to the personal qualities of the insured.

Despite the fact that the insurance contract in this case is concluded by the contractor and its obligations are fulfilled by the contractors, the rights arising from the contract belong to the insured, and the person who has stipulated the contract, even he is the holder of insurance policy cannot validate these rights without the written consent of the insured, in which he says if agrees to the contract on his behalf. The insurer, on whose behalf the contract was stipulated to, has the right to make all the rejections that belong to the person who has signed the contract on his behalf against the insurers, depending on the type of the concluded insurance contract.

On the other side, the person who has signed the contract on behalf of the others, is entitled of the same rights over the insurance amount paid by the insurer, with the occurrence of the insurance case, as the keeper of the loan for expenses incurred for maintaining the loan, for the return of premiums paid to the insurer and the return of the contract costs.

\section{Conclusions}

Insurance contract is related between two parties: the insurer and the insured, where the insured is obliged to pay the price of insurance and within the agreed limits, the insured is obliged to pay the amount of insurance, when the insurance case happens.

The aim of this contract is to transfer the risk from the insured to the insurer.

The will of contractual parties in the insurance contract is expressed through the insurance policy. Albanian Civil Code provides that this form has effects on validity of the contract. Italian Civil Code provides that the insurance policy does not effect on the validity of the contract, but it is only a proof on contract existence.

Both Civil Codes have excluded a certain categories subjects on being part of life insurance contract.

Life insurance contract is concluded in order to provide the life of the insured or a third person.

Life insurance contract in benefit of a third person is concluded if the third person is interested in it and accepts it. The amount of insurance, after the insurance case happens, will be from the insurer to the third person.

\section{Recommendations}

We recommend Albanian legislator in adding some articles on the life insurance contract to regulate the cases when the contract is signed by a person who doesn't have the right. 
Also, we recommend Albanian institutions to take awareness campaign, in order to make known the advantages of insurance contract, especially of life insurance contract.

The authors accept, this article is closely based on Albanian Civil Code and Italian Civil Code with the big objective that in the future will also focus on specific laws and other legal acts.

\section{References}

Albanian Civil Code, 1982.

Albanian Civil Code, 1994

Albanian Ministry of Justice,"Obligations and contracts", Durrës, 1932.

Italian Civil Code.

"Istituzioni di diritto privato" (Diritto civile), X edizione, Edizioni Giuridiche Simone, 2003.

Law no. 2359, 15.11.1956 "On legal actions and obligations", Albania.

Nuni, Ardian, "Veprimet juridike”, Tiranë 2000.

Nuni, Ardian; Mustafaj, llir; Vokshi, Asim "E drejta e detyrimeve II", Tiranë, 2008.

Robinson, J. James, "The history of life insurance", Acronis, USA, 2006.

Roppo, Vicenzo, "Instituzioni di diritto privato", Monduzzi editore, Bologna, 1998.

Roppo, Vicenzo,"I contratti", Giuffré, Milano, 2001.

Semini, Marjana, "E drejta e detyrimeve dhe e kontratave, pjesa e posaçme", Tiranë, 2002. 